\title{
MYCOBACTERIA AND FISH
}

\author{
Saburo SATO \\ Research Institute for Tuberculosis and Leprosy, Tohoku University
}

Since Bataillon et al, first recorded tuberculosis-like disease of a carp in 1897, isolating a strain of mycobacteria, M. piscium from the fish tissue, several works on the subject have been presented by Aronson (1926, see-water fish, M. marinum), Baker \& Hagan (1942 Mexican platy fish, M. platypoecilus), Besse (1949, siamese fighting-fish-M. anabanti), and Ross (1959-salmon and trout-M. salmonifilum-4 strains). (These mycobacteria are designated as M. pis, M. mar, M. pl, M. ana, M. sal for short in the following description.)

The author has isolated 21 strains of mycobactria from 129 fish of 11 species of the tropical fish out of 260 fish of 23 species, (Tables 1-a and 1-b). Besides these he has obtained 3 more strains of mycobacteria culturally from a goldfish and two cruaians which were previously inoculated with leprosy bacilli (strains "Shio" and "C 106") One more strain, "Cc 116 " was the one originated from a crucian inoculated with killed leprosy bacilli. On the other hand, attempts to detect mycobacteria in the viscera of various fresh-, brackish- and see-water fishes, (53 goldfish, 24 crucian, 16 carp, 15 loach, 5 dace, 13 macropodus chinensis, 47 rainbow trout, 21 see-water fishes including a salmon and 4 see-pearch-totaling 170), tinctorially and culturally, ended almost entirely negative. Histological examinations performed in more than 50 fish gave no results.

Although diseased fish sometimes were sluggish and dull in appearance, scarcely and ulceration or tumor was found in the skin. In autopsy, there were seen greyish white, pin-headed or rice grain sized, soft nodules in the viscera, in particular, liver, kidney and spleen in rapidly advanced cases. Abundant acid-fast rods were detected intra- and extra-cellularly of monocytes in the granuloma which resembled considerably to a rat leproma or avian tuberculous granuloma in histology. In slowly advanced cases, however, many miliar nodules resembling to a transverse section of a hyalinized vessel in their appearances, were found in the viscera. (Fig. 2 and 3)

The author has studied on the mycobacteria of the fish origin bacteriologically and immunologically together with some other biological properties. In particular, pathogenicity to goldfish or other experimental animals has been studied comparing with lesions seen in spontaneously diseased tropical fish. The results were summarized as follows:

1) Bacteriology: The 24 strains can be classified into 4 groups according to their cultural properties, in particular, to ability of pigment production conforming to Runyon's classification of atypical mycobacteria. Thus; i) Photochromogens (P-group for short); orange colored pigmentation develops in less than 24 hours after exposing the culture to electric light-60 candle power at distance of $30-40 \mathrm{~cm}$ for 20 minutes. 5 strains, "Lt," "Pl," "Sf2," "Sp," "Sw". ii) Scotochromogens (S); bright orange color is formed even in the dark. 9 strains, Bm2, Gp, C106, Cc116, Pg3, Pg4, Pg6 $\mathrm{Sf3}, \mathrm{Tp2}$. iii) Nonphotochromogens $(\mathrm{N})$; greyish white colonies. 7 strains, Bm1, Bg, Bt, Pg1, Pg5, Sf4, Shio. iv) Delayed photochromogens (provisional designation, P'-group). 3 strains, Pg2, Sf1, Tp1. Optimal temperature for growth are found ranging from $25^{\circ} \mathrm{C}$ to $30^{\circ} \mathrm{C}$. All of the strains grow well on egg media and on heart infusion agar slant. Strongly acid-fast rod resembling tubercle bacillus. "Bt" is slender in size. "Pl," "Sf2" "Sp" "Sw" are generally dicker and longer in size than tubercle bacillus, especially in the fish tissue, whereas they are shorter on cultue media, showing somewhat pleomorphic tendency. Formation of pellicle in liqued media is mostly difficult to be seen in the strains of "S" and "N"-groups. No typical cord formation could be seen except for in $\mathrm{Lt}, \mathrm{Bm} 2, \mathrm{Bg}$, Bt. (Fig. 6) Viability of the bacilli stored in physiological saline at room temperature; majority of the strains retained their flourishing activity for more than 9 months in a saline. Neutral red reaction are mostly positive. Pg1 and Sf1 were strongest while strains of P-group generally gave weak reaction. Strains "C106" and "Cc116" were negative for the test. 
Table 1-b Number of tropical fish from which no acid-fast bacilli were isolated in spite of positive bacillary finding in smeared or sectioned specimen

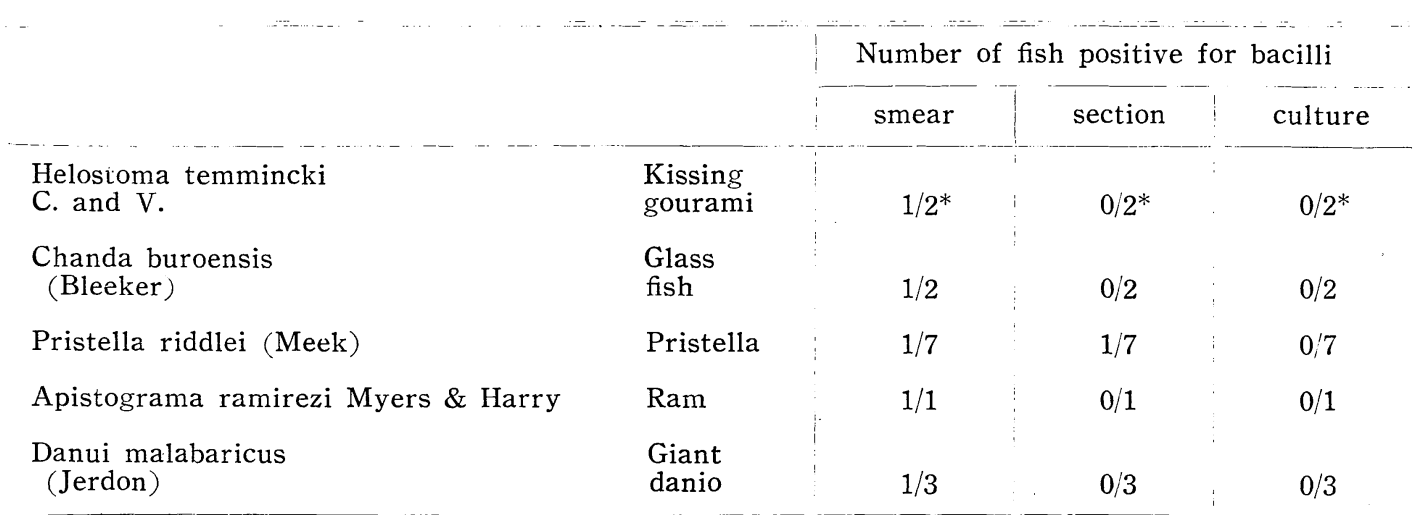

No acid-fast bacilli were detected both, tinctorially and culturally in the following 6 sorts of tropical fishes (3 or Hemigrammus ocellifer, 4 of Hyphessobrycon innesi, 7 of Pterophyllum eimekei, one Hemichromis bimaculatus, 5 of Barhns tetrazona and 5 of Brachydanio rerio.

* A denominator signifies total number of fish examined and a numerator number of cases positive for bacilli.

Table 1-a Name of tropical fish from which acid-fast bacilli were isolated

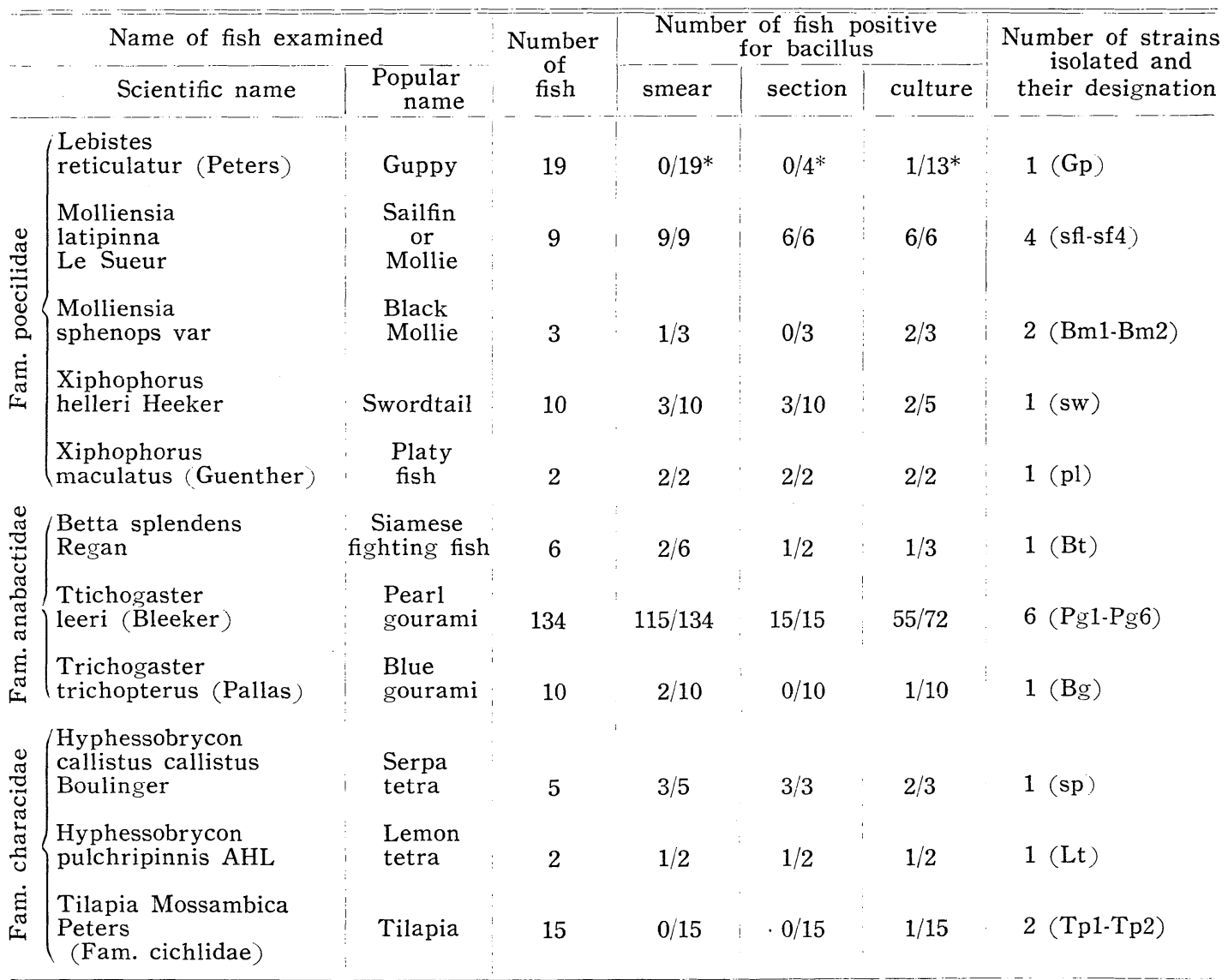

* A denominator signifies total number of fish and a numerator number of cases positive for bacilli. 
2) Drug resistance: Majority of the strains can grow well on egg-media containing PAS $2 \mathrm{~m} / \mathrm{ml}$ except for 2 strains of $M$. sal. As shown in Table 2, many of the strains showed strong resistance to INH, 1314Th, chloromycetin and streptomycin except for 2 strains of P'-group, Pg2 and Sf1.

3) Enzyme activity: Majority of the strains exhibited strong catalase activity. As shown in Table 3, formamidase test is negative in all of them except for " $\mathrm{Bg}$ " and 4 strains of $\mathrm{M}$. sal. Not a few strains had nicotinamidase activity. Urease reaction were strongly positive in many strains excluding two, "Bg," and "Shio". Niacin test; it was highly emphasized that the 4 of the photochromogens together with M. P1 and M. mar. showed positive for the test. Besides this, " $\mathrm{Bg}$ " and 4 strains of M. Sal. were also positive, though weak and inconstant, for the test (Table 3).

4) Immunological properties: Sera of goldfish infected with "Sp" and "Pi" strains were capable of agglutinating both of them reciprocally (Table 4-a and 4-b). Cross immunity among the strains were clearly demonstrable by routine agglutination test using rabbit antisera and by Ochterlony's gel-diffusion method (Fig. 4-a and 4-b). Tuberculin allergy did not arise in guinea-pigs inoculated with “Sp", "Sw", "Sf1" Pg3 and Bm2 even after 6 weeks.

5) Inoculation experiments : Almost no noteworthy lesions were produced in rabbits, guineapigs, mice and chickens. Virulence of the strains apparently seemed to be weak against warm blooded animals. On the other hand, goldfish $(7-10 \mathrm{~cm}$ in body length) inoculated with the mycobacteria of the fish origin $(0.1 \mathrm{mg} / 0.1 \mathrm{ml})$ caused generalized infection identical to that of spontaneously diseased tropical fish. It was revealed that intramuscular inoculation was favorable for evaluation of the infection than intraperitoneal injection inasmuch as the effect of mechanical violences on fish by injection were avoidable. Although the study is not yet thoroughly performed, generally speaking, pathogenicity of strains of P-group seems to be strongest and constant, followed by $\mathrm{Bm} 2, \mathrm{Bt}, \mathrm{Cc} 116, \mathrm{Pg} 1, \mathrm{Pg} 5$ and $\mathrm{C} 106$ etc. Toxity of $\mathrm{Bg}, \mathrm{Pg} 2$, Pg3, Sf3 seemed to be rather weak or almost avirulent. However, the virulence of every strain seemed to be influenced considerably by breeding condition. If the condition was kept favorably, the fish would remain alive for $1 / 2-1$ year
Table 2 Drug resistance of Mycobactria isolated from tropical fishes. Comcentration : $\gamma / \mathrm{ml}$

\begin{tabular}{|c|c|c|c|c|c|}
\hline \multicolumn{2}{|c|}{ Strains } & I N H & 1314 & $\mathrm{CM}$ & $\mathrm{S} M$ \\
\hline \multirow{8}{*}{$\mathrm{P}$} & Lt & $<10$ & $<20$ & $<20$ & $<50$ \\
\hline & P1 & $<10$ & $<20$ & $<50$ & $<20$ \\
\hline & Sf2 & $<10$ & $<5$ & $<50$ & $<20$ \\
\hline & $\mathrm{Sp}$ & $<10$ & $<10$ & $<20$ & $<10$ \\
\hline & SW & $<10$ & $<10$ & $<20$ & $<10$ \\
\hline & $\mathrm{PL} *$ & $<10$ & $<10$ & $<50$ & $<20$ \\
\hline & Pis* & $<10$ & $<10$ & $<50$ & $<50$ \\
\hline & Mar* & $<20$ & $<10$ & $<50$ & $<50$ \\
\hline \multirow{5}{*}{ S } & $\mathrm{Bm} 2$ & $<10$ & $>50$ & $>100$ & $<20$ \\
\hline & $\mathrm{Gp}$ & $<10$ & $<20$ & $<100$ & $<20$ \\
\hline & Pg3 & $<5$ & $<10$ & $<50$ & $<20$ \\
\hline & Sf3 & $<5$ & $<10$ & $<50$ & $<100$ \\
\hline & $\mathrm{Tp} 2$ & $<50$ & $<20$ & $<50$ & $>100$ \\
\hline \multirow{7}{*}{$\mathrm{N}$} & $\mathrm{Bg}$ & $>50$ & $>50$ & $>100$ & $>100$ \\
\hline & $\mathrm{Bt}$ & $>50$ & $>100$ & & \\
\hline & $\operatorname{Pg} 1$ & $>50$ & $>100$ & $>100$ & $>100$ \\
\hline & Pg5 & $<1$ & $<100$ & $<20$ & \\
\hline & Shio & $>50$ & $>100$ & $<50$ & $>100$ \\
\hline & M32* & $<20$ & $<50$ & $<20$ & $<100$ \\
\hline & Sal.Sc* & $<10$ & $<100$ & $<20$ & $<100$ \\
\hline \multirow{2}{*}{$\mathrm{P}$} & Pg2 & $<10$ & $<5$ & $<5$ & $<1$ \\
\hline & Sf1 & $<5$ & $<5$ & $<10$ & $<1$ \\
\hline
\end{tabular}

* P1‥M. Platypoecilus; pis...M. piscium; $\operatorname{mar} \cdots$ M. marinum; M32 and sal SC...Mycobacteria isolated from a tropical fish and a salmon respectively, by Ross.

P...Photochromogen ; S...Scotochromogen ; N... Nonphotochromogen.

$<10 \cdots$ Inhihited growth in $10 \gamma / \mathrm{ml}$-concentration.

$>100 \cdots$ luxuriant growth in $100 \mathrm{\gamma} / \mathrm{ml}$-concentration. 
Table 3 Amidase activity of mycobacteria of fish orgins with refererence to the Niacin test.

\begin{tabular}{|c|c|c|c|c|c|}
\hline \multicolumn{2}{|r|}{$\begin{array}{c}\begin{array}{c}\text { Enzymes for } \\
\text { examination }\end{array} \\
\text { Strains }\end{array}$} & Formamidase & Nicotinamidase & Urease & Niacin test \\
\hline \multirow{4}{*}{$\mathrm{P}$} & Lt, M. Pis. & - & - & $H \sim H$ & - \\
\hline & $\mathrm{P} 1, \mathrm{St} 2, \mathrm{Sp}, \mathrm{Sw}$ & - & + & H & $H \sim H$ \\
\hline & M.PL. & - & + & H & $H \sim H$ \\
\hline & M. Mar. & - & $H$ & H & \pm \\
\hline & $\{\mathrm{Bm} 2, \mathrm{Gp}, \mathrm{Pg} 3, \mathrm{Sf} 3$ & - & - & H & - \\
\hline & ไCC-116 & - & - & + & - \\
\hline \multirow{5}{*}{$\mathrm{N}$} & Shio. & - & - & - & - \\
\hline & $\mathrm{Bg}$ & + & - & - & $+\sim \ldots *$ \\
\hline & M. Sal. CC & $t$ & + & H & $+\sim-^{*}$ \\
\hline & M. Sal. SC & + & - & H & $+\sim-*$ \\
\hline & M. Sal. CAR \& OR & $H \sim H$ & + & H & $+\sim-*$ \\
\hline \multicolumn{2}{|c|}{$\mathrm{P}^{\prime} \quad \mathrm{Sf} 1$} & - & + & + & - \\
\hline
\end{tabular}

$+\sim \sim^{*}$; Reactions were in weak and results were inconstant.

Symbols signify the same thing as those shown in Table.

Table 4-a Agglutionation test between sera of gold-fish infected with the strain "Sp" or "Pl" and bacilli suspension of "Sp"

\begin{tabular}{|c|c|c|c|c|c|c|c|}
\hline \multirow{2}{*}{$\begin{array}{l}\text { Bacilli } \\
\text { infected }\end{array}$} & \multirow{2}{*}{$\begin{array}{l}\text { Number of } \\
\text { fish sera }\end{array}$} & \multirow{2}{*}{$\begin{array}{l}\text { Elapsed days } \\
\text { after infection }\end{array}$} & \multicolumn{5}{|c|}{ Dilution of sera } \\
\hline & & & 20 & 40 & 80 & 160 & 320 \\
\hline \multirow{5}{*}{$\mathrm{Sp}$} & 1 & 141 & H & + & + & + & \pm \\
\hline & 2 & 183 & $H$ & H & + & $H$ & $H$ \\
\hline & 3 & 190 & H & $H$ & $H$ & + & \pm \\
\hline & 4 & 211 & H & H & H & + & + \\
\hline & 5 & 255 & H & $H$ & + & + & + \\
\hline \multirow{4}{*}{$\mathrm{Pl}$} & 2 & 97 & $H$ & H & $H$ & + & + \\
\hline & 3 & 118 & H & H & H & + & + \\
\hline & 4 & 132 & H & H & H & H & + \\
\hline & 5 & 162 & H & H & + & \pm & \pm \\
\hline \multirow{4}{*}{$\begin{array}{l}\text { Control } \\
\text { Group }\end{array}$} & 1 & & $H$ & + & \pm & - & - \\
\hline & 2 & & H & + & + & \pm & - \\
\hline & 3 & & - & - & - & - & - \\
\hline & 4 & & + & \pm & - & - & - \\
\hline
\end{tabular}

and over. In histology, the lesions developed in the fish tissue were characterized with formation of miliar nodules or granulomas identical to the lesions found in the diseased tropical fish above mentioned.

On the other hand, the author performed inoculation experiments to the goldfish with leprosy, and tubercle bacilli and 4 strains of atypical mycobacteria together with 7 straius of saprophytic 
Table 4-b Agglutination test between sera of gold-fish infected with the strain "Sp" or "Pl" and bacilli suspension of "Pl"

\begin{tabular}{|c|c|c|c|c|c|c|c|}
\hline \multirow{2}{*}{$\begin{array}{l}\text { Bacilli } \\
\text { infected }\end{array}$} & \multirow{2}{*}{$\begin{array}{l}\text { Number of } \\
\text { fish sera }\end{array}$} & \multirow{2}{*}{$\begin{array}{l}\text { Elapsed days } \\
\text { after infection }\end{array}$} & \multicolumn{5}{|c|}{ Dilution of sera } \\
\hline & & & 20 & 40 & 80 & 160 & 320 \\
\hline \multirow{5}{*}{ Pl } & 1 & 49 & + & + & + & + & - \\
\hline & 2 & 97 & + & + & + & \pm & \pm \\
\hline & 3 & 118 & H & $H$ & H & + & + \\
\hline & 4 & 132 & + & + & + & + & \pm \\
\hline & & 162 & H & $H$ & + & + & \pm \\
\hline \multirow{4}{*}{$\mathrm{Sp}$} & 2 & 183 & + & + & \pm & \pm & - \\
\hline & 3 & 190 & $H$ & H & Hit & + & + \\
\hline & 4 & 211 & Ht & Hit & H1 & H & + \\
\hline & 5 & 255 & H & H & H & H & + \\
\hline & 1 & & H & + & \pm & \pm & - \\
\hline Control & 2 & & \pm & 一 & - & - & - \\
\hline \multirow[t]{2}{*}{ Group } & 3 & & + & - & - & - & - \\
\hline & 4 & & \pm & - & - & - & - \\
\hline
\end{tabular}

mycobacteria, examining the results obtained bacteriologically, immunologically and histopathologically in comparison with the results obtained by inoculation test with the mycobacteria of the fish origin.

Although leprosy bacilli, murine leprosy bacilli, tubercle bacilli, a strain of saprophytic mycobacteria were found tinctorially over 1-2 years (742,757, 397 and 441 days respectively), and that the latter four kept their viability, at least 12, 4 and 6 months long after the inoculation in the fish tissue respectively, producing slight lesions in the fish body. It was clear that these mycobacteria were not pathogen, though not indifferent, to the fish. Contrary to these fiindings, of the 4 strains of atypical mycobacteria, 3 were found to be virulent to goldfish as almost similarly as mycobacteria of the fish origin. The 3 were P6 (Scotochromogen), P7(Non photochromogen) and P8 (Photochromogen). Every strain injected into the muscle at the site between the back-fin and side-line. It was revealed that the agents inoculated caused generalized infection after 3-4 weeks, forming miliar tubercles in the kidney, spleen or liver etc.

Although the study is going on and further and elaborate scrutinization should be required, the facts that there exist many similarities in bacteriological, immunological and other biological properties between atypical mycobacteria group and mycobacteria group of the fish origin are full of suggestion in solving the relationship between the two groups, and between each of the two and saprophytic mycobacteria groups. Furthermore, it is emphasised that there are much more strains of mycobacteria associated whith the cause of tuberculosis-like disease of the fish besides M. marinum and M. platypoecilus, both of which alone are accepted as mycobacteria concerned in the Bergey's Manual of Determinative Bacteriology. (7th edition, 1958). 


\section{写 真 説 明}

Fig. 1 Photomicrograph showing a formation of miliar nodules in the spleen of a goldfish inoculated intramucularly with a scotochromogenic strain P6 of atypical mycobactria and, killed 161 days after. Bacilli and masses of pigment were seen. Ziehl-Neelsen, $20 \times 20$.

Fig. 2 Photomicrograph showing a murine leproma-like granuloma seen in the liver of a tropical fish, molliensea latipinna Le Sueur. Ziehl-Neelsen, $20 \times 10$.

Fig. 3 Photomicrograph showing a formation of miliar nodules, resembling to a transverse section of a thrombosed vessels, in the kindney of a tropical fish xiphophorus helleri Heeker. Big bacilli masses are seen. Ziehl-Neelsen, $20 \times 20$.

Fig. 4 Ultra-thin section of the kidney of a carp inoculated intramuscularly, with mycobacteria, "Sp" strain, isolated from a tropical fish and killed after 227 days. Showing a transverse section of three bacilli (Myc) enclosed by capsule-like memberane with uniformly dense body (U-equivalent to "opaque droplet"). Capsule spaces (CS) are clearly shown.

Fig. 5 Ultra-thin, longitudinal section of a strain "Sp" of mycobacteria of the fish origin, cell wall, endoplastic memberane, nuclear site, mitochondrial equivalent ( $M$ ) were seen. A cell in dividing process is clearly shown (arrow). MpB …...Metaphosphated bodp.

Fig. 6 Showing a cord-formation of a strain Lt of mycobacteria of the fish origin, cultivated in Lockemann's media added serum for 4 weeks. Zieh1-Neelsen, $20 \times 20$.

Fig. 7 Absorption spectra of pigments obtained from two strains of mycobacteria ("SP" and "Pg3") and a carrot.

Fig. 8 A homologous precipitation reaction between antiserum of strain "P1" isolated from a fish (in a middle well) and antigens of 6 strains of mycobacteria (in outer wells, No. 1-No. 6). The antigens were prepared from a filtrate of 4-5 weeks old culture on Lockemann's media (a luxuriant pellicle formation) by concentration to $1 / 10$ volume on the water-bath at $62{ }^{\circ} \mathrm{C}$. Symbols; $1-5 \cdots \cdots$ antigens of 5 strains, Sp, Sw, Sf1, Sf2, and P1 in the order designated, all

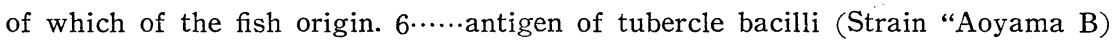

Fig. 9 A almost homologous precipitation reaction between antiserum of strain "P1" isolated from fish (in a middle well) and antigens of 6 strains of mycobacteria (in 6 outer wells, No. 1-6). The antigens was prepared in quite the same ways as described in Fig. 8. Symbols; 1 and $2 \ldots \ldots$ antigens prepared from strains "Sf1" and "Bm2" respectively, both isolated from fish. $3 \cdots$ an antigen of a strain P8 of atypical mycobacteria. $4 \cdots$ an antigen of M. salmonifilum SC

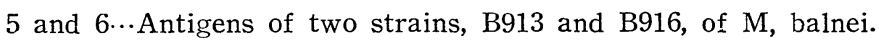

Fig. 10 Photomicorgraph showing formation of numerous miliar nodules contaiming bacilli in the heart (ventricle and auricle) of a goldfish inoculated intramusclarly with strain "Sp", mycobacteria of the fish origin, and killed 178 days after. Ziehl-Neelsen, $20 \times 4$.

Fig. 11 Photomicrograph showing a nodule found in the liver of a goldfish inoculated intramuscularly with strain "P1", a sort of mycobacteria of the fish origin, and killed 131 days after. A nodule resembling to a transverse section of a hyalinized vessel contains bacilli masses. Zieh1Neelsen, $20 \times 40$. 


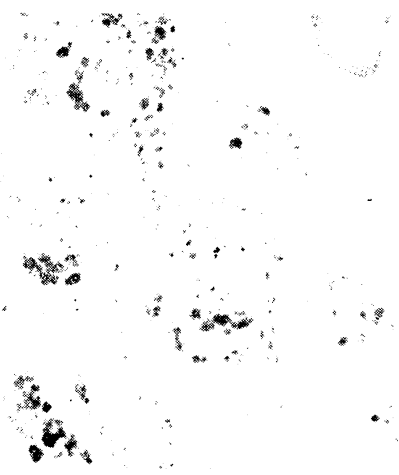

Fig. 1

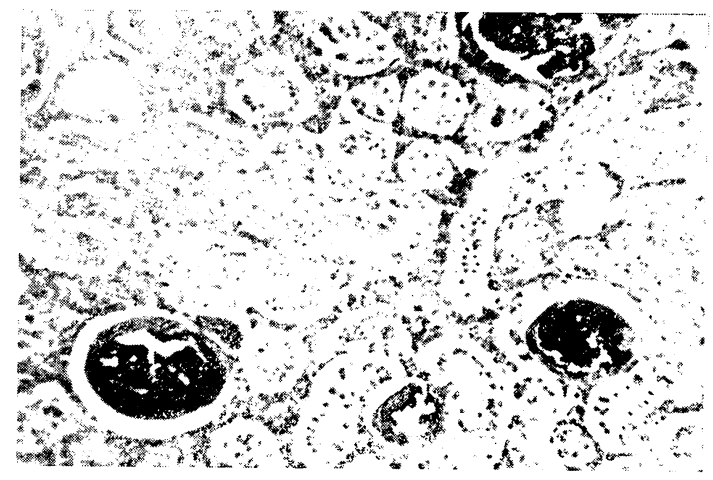

Fig. 3
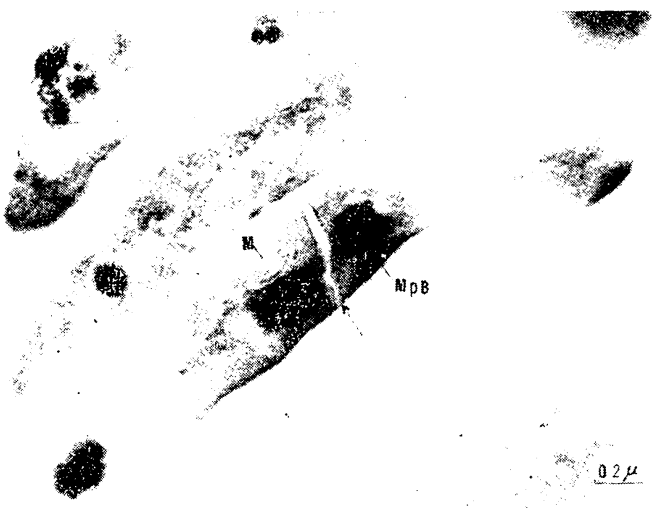

Fig. 5

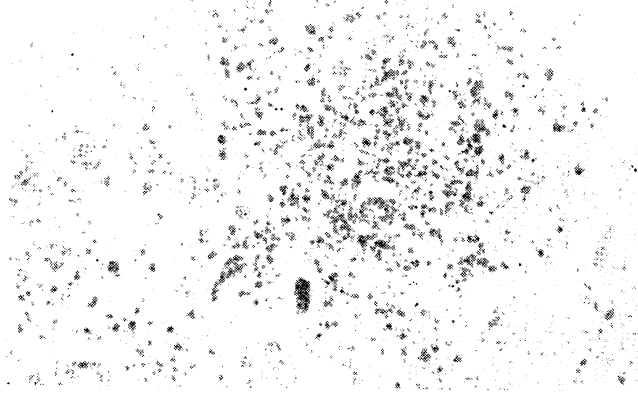

Fig. 2

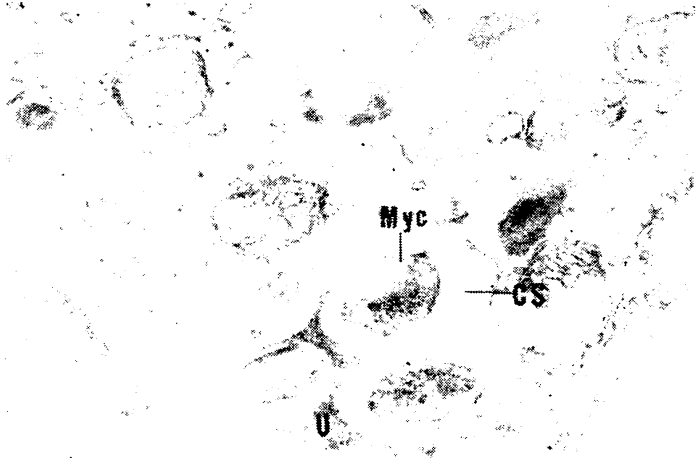

$0.2 \mu$

Fig. 4

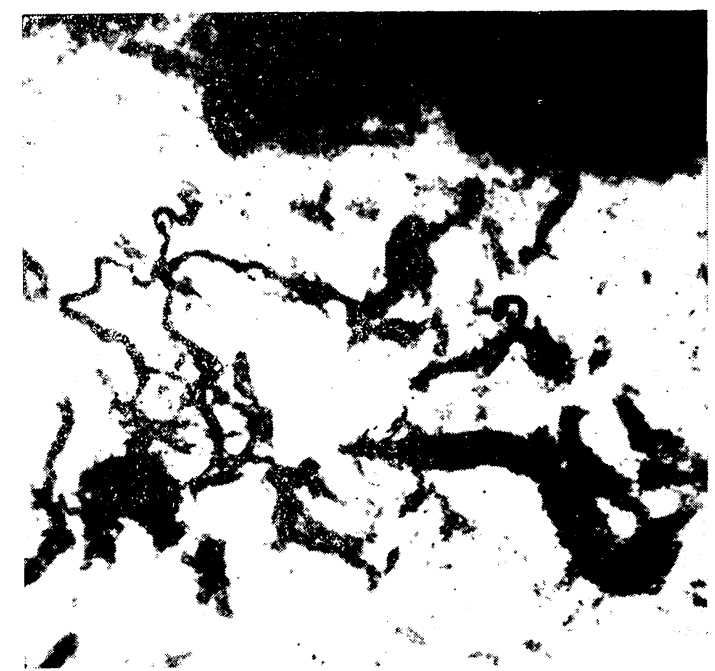

Fig. 6 
Fig. 7. Absorption spectra of pigments obtained from two strains of mycobacteria ("Sp" and "Pg3") and a carrot.

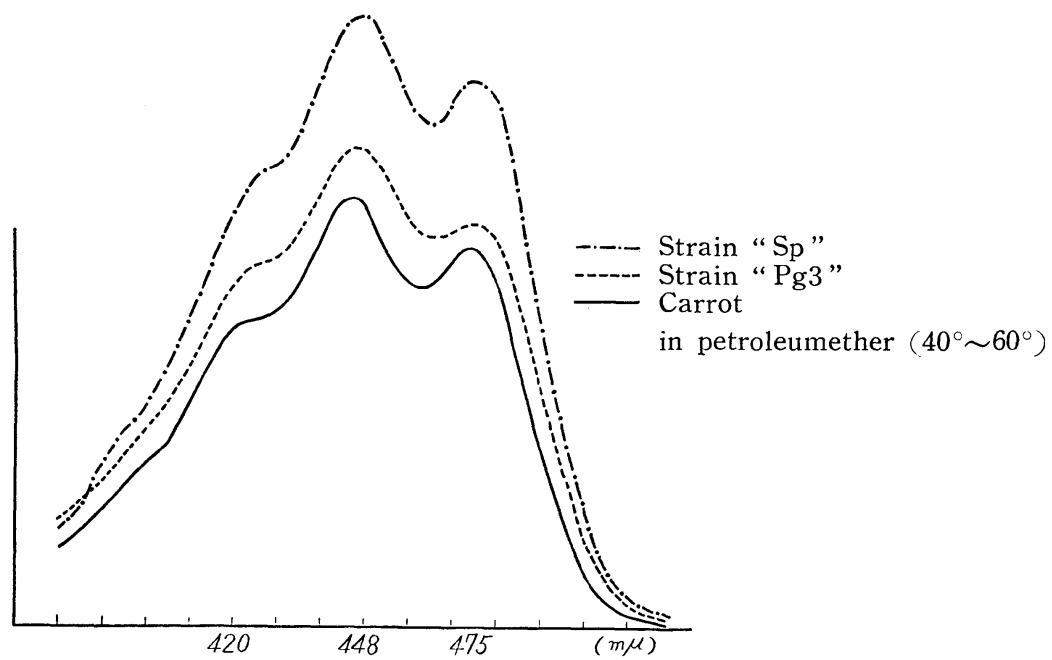

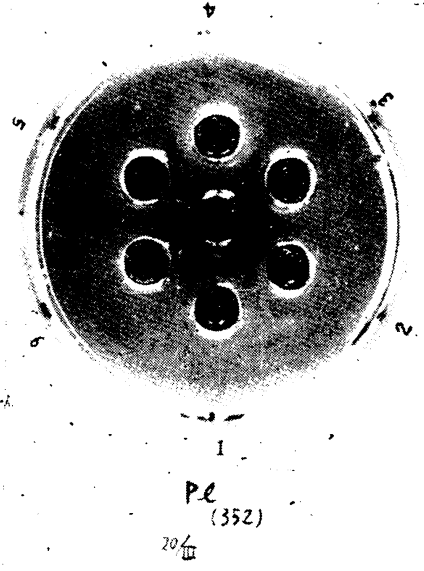

Fig. 8
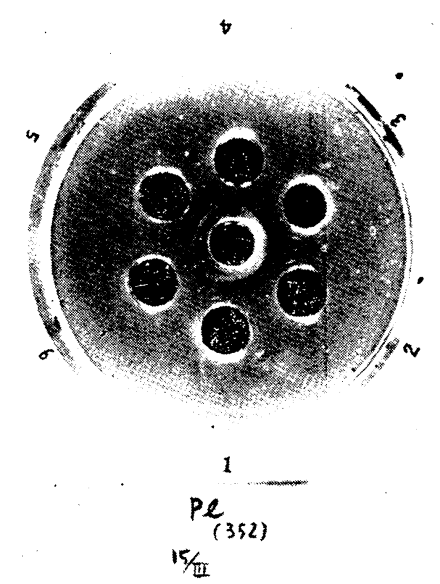

Fig. 9

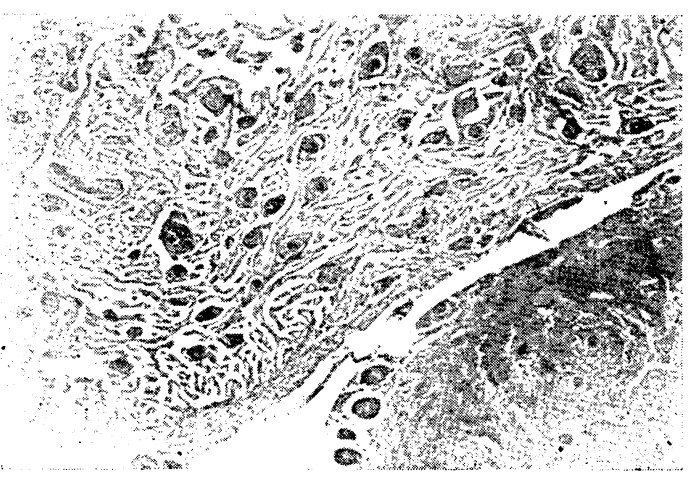

Fig. 10

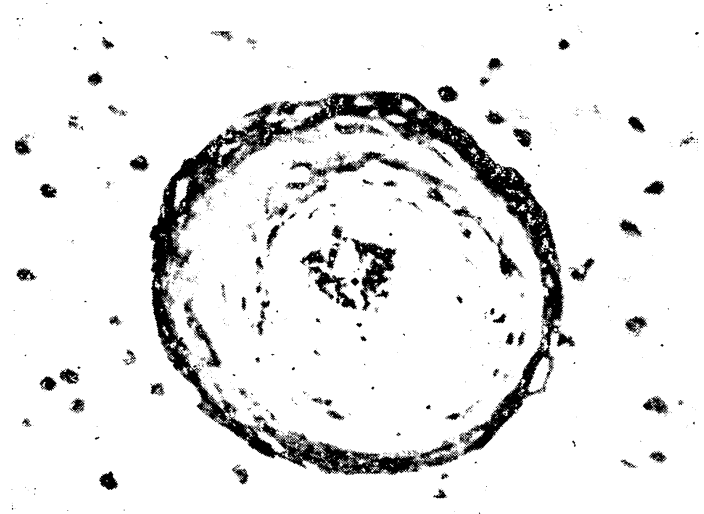

Fig. 11 
抗酸菌と魚類

1897 年 Bataillon et al ${ }^{11}$ が結核様乃至癩様疾患を持 つ鯉から M. piscium を分離し，魚類にも抗酸菌症のあ ることを明らかにした。 Parisot ${ }^{2)}$ によると当時てれが 結核菌の魚体内での変異を示すかどうかをめぐって多く の実験之議論が行われた。Bertarelli et al (1910) ${ }^{3)}$ は 多くの海水魚を調べて自然の状態ではこれらに抗酸菌症 はほとんどあるまいと述べたが, その後Alexander ${ }^{4)}$ Sutherland ${ }^{5)}$ は鱈の 1 種に狼瘡様疾患を見たとし, 1926 年 Aronson ${ }^{6)}$ は水族館飼育の海水魚に時折結核様疾患 を見たという Winsor の言からこ扎を調査して， M. marinum を分離し, その細菌, 病理, 免疫学的研究を 公にした。水族館飼育の熱帯魚にこの種疾患を見ること は稀でなく 1942 年 Baker and Hagan ${ }^{7)}$ は platy fish から M. platipoecilus (M. PL) を分離, 1949 年には Besse $^{8)}$ が paradise fish 含む多数の熱帯魚から抗酸 菌を分離して M. anabanti と呼えだ。後年 Vogel ${ }^{9)}$ は 本疾患の分布は 10 目, 34 科, 84 属 120 種の淡水, 海水産 の魚にわたると称した。鮭類についても Earp et al ${ }^{10)}$ Wood et $\mathrm{al}^{11)}$ の発見に続き最近 Ross ${ }^{12)}$ による M. Salmonifilum（鮭菌と略す）の分離が報ぜられた。以上 魚の結核様疾热については Aronson ${ }^{13)} ゃ$ Parisot $^{2)} の$ 総説にくわしい。

一方, 癩と魚との関連については古くHutchison ${ }^{14)}$ や Creighton ${ }^{15)}$ による Fish-theory があり癩発病と 腐魚嗜喰との関係が宣伝されたがもとより根拠のない議 論である。ただ, 近年, Bergel ${ }^{16)}$ は魚はGの所謂 proxidant の食物で癩感染に促進的に劺らくこ述へた。

以下私はまず病原, 韭病原の諸種抗酸菌の金魚, 鮒へ の接種試験の成績を述べついで熱帯魚その他からえた 多数の抗酸菌株の生物学的性状や金魚への接種試験の成 績を記し，さらにこれらと人の非定型抗酸菌との関連に ついても言及しよう。

\section{1）金魚，鮒などに対する癩菌その他病原 非病原性抗酸菌の接種試験}

成績の一部は既に公表した。17)18)

癩菌：菌液（20-100 倍結節乳剤の 1000 回 2 分遠心後 の上清) $0.1 \mathrm{ml}$ を $4-8 \mathrm{~g}$ の金魚の, $0.5 \mathrm{ml}$ を $35-70 \mathrm{~g}$ の金 魚の各腹腔内に接種した場合, 菌は 2 年余にわたってほ とんど毎常内臓殊に肝, 脾, 腸間膜, 卵栄などに証明で

\section{(東北大 抗研) 佐 藤 三 郎}

き, しかも細胞内に小塊をなし, 集まって肉芽腫を形成 し増殖したかのような所見を呈することが屢々だった。 しかしその周辺に組織反応の著しいものがなく，対照の 煮沸菌接種群にもほぼ似た所見が見られた。鼠癩菌(ほ ぼ瀬菌の場合と同じ操作で菌液を作ったが菌量はずっと 多い）ではさらにいっそう増殖を思わせる所見に接す る。しかも接種後 1 年までは少なくとも菌の生存が確証 された。しかし共に累代接種には成功しなかった。筋肉 内に接種した場合はなお観察中であるが，接種局処にお ける菌の増殖は癩菌，鼠瀬菌共確実ではなく内臓に菌が 侵入するととあ少ないようである。熱帯魚 Trichogaster leeri または Tilapia mossambica による実験は 供試魚自体が既に抗酸菌症を有しており，判定不能であ った。なお Chaussinand et al ${ }^{19)}$ は Eupomotis gibos sus の腹腔内で20力月も鼠瀬菌が生存する上し, 高山 ${ }^{202}$ の鮒での実験では259日であった。

結核菌：青山 $\mathrm{B}$ 株 $0.1 \mathrm{mg} / 0.1 \mathrm{ml}$ を $5 \mathrm{~g}$ 前後の金魚の腹 腔内に接種したが，菌は 400 日以上も内藏中にも証明で き小塊を作っていたが，復原培䍿では 4 力月まで陽性だ ったに過ぎない。

自然界抗酸菌：水系 5 ，土系 1 ，動物系 1 (モル亚株） の 7 株について $0.1 \mathrm{mg} / 0.1 \mathrm{ml}$ を腹腔または皮下に接種 したが，菌株により金魚に対する毒力を多少異にする が，それよりも接種法による差が大きく，腹腔内に接種 されたモルIII株の如きは 400 日後む内蔵中に残存し, 復 原培養む 9 力月まで可能であった。土系の 1 株む腎に多 数の菌を持つ小結節を作った。しかし皮下に接種された 多くの水系の菌はおおむね，速やかに消失するもののよ うであった。中村 ${ }^{21)}$ は雑系抗酸菌鯡鮒の腹腔内に 10 $\mathrm{mg}$ の大量注射し 7 週後にかなりの涡変劣認めている。 以上の接種実験例のすべてについて剖検時, 朋, 脾, 腎,

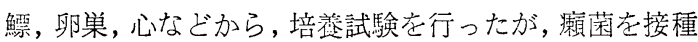
した金魚（塩谷株）鮒（C106 株）から各 1 株，および 瀬死菌を接種した鮒より 1 秼（Cc 116 株）の抗酸菌を 分離し得た以外，全例陰性に終った。しかも上記 3 株の 菌は金魚, 鮒計 170 尾の内臟計約 800 個についての培盖 成績である。

非定型抗酸菌：P1, P6, P7, P8 の 4 株を各 $0.1 \mathrm{mg} / 0$. $1 \mathrm{ml}$ ずつ 7〜 $8 \mathrm{~cm}$ 長の金魚の筋肉内に接種した。 $\mathrm{P} 1$ 株 と P8 株は Photochromogens, P6 株は Scotochromo- 
gens, P7 株は Non-photochromogens に属する。6力 月にわたる観察によると $\mathrm{P} 1$ 株は病原性少なく局処に菌 をむつ肉芽腫を作るが，内臟では微細結節を作ってもそ の中の菌は速やかに消隇した。しかるにほかの株はかな りの病原性を示し, 接種部に慢性の肉芽腫を作り, 腎, 肝，脾，心などにも間質に菌を容れた細胞が現われ，殊 に腎，脾，筋肉に微細な結核結節の形成さえ見られた。 (Fig. 1)

\section{2）金魚その他養殖, 天然の淡水魚, 海水 魚についての抗酸菌症の探索}

㭘査の方法は体表および内臟の外観を調べた後, 各臓 器の塗抹標本を作って抗酸菌の有無を検し, 肝, 腎, 脾に ついては毎常, その他の藏器については時折, 小川法によ り培羑 $25^{\circ} \mathrm{C}$ (時には $37^{\circ} \mathrm{C} に$ に) 2 力月間放置した。 それによると金魚53 (宫城, 山形,大和郡山産), 鮒24(内

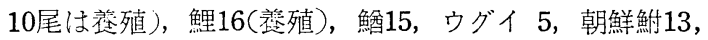
虹鱒 47 , 鮭及ご川鱒各 1 ， その他イシダイ 6 ，スズキ 4 を含む21尾の海水魚では 1 例の朝鮮鮒 Macropodus chinensis (Bloch) で肝に数コの抗酸性桿菌?を認めた （切片，培盖は陰性）以外, 全例すべて塗抹, 切片, 培 荃各試験が陰性に終った。

しかるに市販の熱带魚 7 科 23 種計 260 個体についての 調査では次のような興味ある成績を得た。すなわち a) 塗抹陽性, 切片陽性で培養も陽性だった場合，4科11種 計 215 尾（内 129 例は全例培養陽性） b) 内臟の塗抹や 切片中に菌を認めながら培羝陰性だった場合， 5 科 5 種 15尾，c）塗抹も切片も菌陰性で培養も陰性に終った場 合， 3 科 17 種計 30 尾，となる (Table 1-a and b)。 結局 11 種の魚から 21 株の抗酸菌が培養分離されたが, 魚を科別に見ると胎性目高科 Fam. poecilidae 5 種か ら 9 株, キノボリウオ科 Fam. anabantidae 3 種から 2 株, シクリッド科 Fam. cichlidae 1 種から 2 株とな る。乙机らの魚は 6 力処の水族館より入手したが， そ の最初の源は香港およびタイ国から輸入された魚と思わ れ, 大部分が香港の 1 業者から供給, 国内で繁殖された あのの子孫と考えられた。

\section{3）熱帯魚の抗酸菌症}

重症に潰瘍を見たものはなく外観上特記すべきものが なかった。剖検的には高度の場合, 肝, 腎時に脾に粟粒大 から半米粒大の灭白色の結節の形成があり, 稀に焱黄褐 色の腹水の潴溜を見るが, 肉眼的にはさしたる変化を見 ないととが多い。各臟器の塗抹標本中には病変に応じて 少数または多数の抗酸性桿菌が見られ殊に結節部では大
小の菌塊が純培荃を見るように集まっている。組織学的 には高度の場合は組織球または単球が集まって大小の肉 芽腫を作り，往々壊連巣むあるが乾酪化というほどのす のは少ない。夥多の菌を密にいれた細胞の集塊はあたか あ鼠癩腫を見るようで (Fig. 2) その周辺には小許の円 形細胞を見るが，ほとんどこれを欠くものが多い。比較的 軽症で慢性に経過したと思われる例では心, 肝, 脾, 腎殊 に腎に粟粒大の結核結節が形成されるが，それは類円形 をなした類上皮細胞の集塊で相融合して類壊㡺化して泡 沫様となり, 遂には硝子様変性に陥ってエオジンで淡紅 染した無構造物と化し，その周辺はへマトキシリンで青 染した細長い細胞の斛でとり巻かれ，一見内腔が閉塞し て硝子様変性に宿った小血管の横断面を見る観がある。 （Fig. 3） 細胞内に密につまった菌は細胞の融崩が進む につれ集まって大小の菌塊を作る。しかし古くなると周 囲の輪を残して無構造物と化し菌はほとんどと消失し, 時に消粍色素をとどめる。時には多数の黑褐色のメラニ ン色素塊を菌と共に持つ結節あある。ズダン亚染色で特 に染まる脂肪粒は認められなかった。超薄切片による電 顕像では人の癩腫によく似た所見を゙呈し，細胞質内の多 数の菌は分裂の種々な過程を示し, 定型的ではないが所 謂 opaque droplets や lipid droplets に相当する顆粒 む見られ，菌をとり巻く capsule enclosing membrane や capsule space の明らかなむのむあった (Fig. 4)

\section{4）熱帯魚および金魚，鮒より分離した 抗酸菌の性状}

熱帯魚より分離した上記 21 株の菌と癩菌を接種した金 魚, 鮒よりえた既記の 3 株（塩谷株， C106株， C C 116 株）計24株について菌学的性状の概略を述べ, 要に応じ て Ross 氏より送られた M. piscium (M. pis) M. marinum (M. Mar) M. platypoecilus (M. P1) および M. salmonifilum (鮭菌, Cc, Car, OR, SC の 4 株) と M32 株（同氏 ${ }^{22}$ が Serpa tetra より分離したむの）や その他の衆知の抗酸菌と比較する。

a）集落：まずその色調を Runyon ${ }^{23)}$ が非定型抗酸 菌で行った方法に筂じ $(40 〜 60 \mathrm{~cm}, 60$ 燭光，15〜 60分照 射）光発色性によって分類すると，Photochromogens (以下P群) 5 株 (Lt, Pl, St $2, \mathrm{SP}, \mathrm{SW}$ ), Scotochromogens ( $\mathrm{S}$ 群) 9 株 (Bm2, C106, Cc116, Gp, Pg3, Pg4, Pg6, Sf3, TP2), Nonphotochromogens (N 群) 7 株 (Bg, Bm1, Bt, Pg1, Pg4, Sf4, 塩谷) となり, この 21 株は通常，厚薄種々の表面や顆粒状をなす湿潤した菌 苔を作る。しかるに他の 3 株（Pg2, Sf1, Tp1） は結核 菌様の乾燥して半球状に隆起した $3 \sim 4 \mathrm{~mm}$ 径の酦譬の 
多い集落を作り，融合すれば凹凸あるやや硬くて厚い菌 苔となり，小川培地ではその基底を黄褐色に変ぜしめ る。集落の色ははじめ淡黄灰白及至淡褐黄色であるが曝 光により $3 \sim 10$ 日で次第に黄褐色の度学増し, 少し古 くなると橙黄褐色上さえなる。この 3 株は勿論 Runyon のいう $\mathrm{P}$ 群ではないが自然界抗酸菌を室内に辰く放置す る時, 集落の色調に変化をきたす場合のそれとも趣を異 にすると思放れ，かりに Delayed photochromogens ( $\mathrm{P}^{\prime}$ 群) と呼えでおく。越智 ${ }^{24)}$ らは室内 7 日聞の放置で 強い色調の変化をきたした非病原性抗酸菌の 3 株をあげ ている。それはさておき $\mathrm{P}$ 群は露光により微黄褐灰白色 の集落が一夜で登黄色に変るが人の非定型菌に比し遙か に着色度が強く又菌苔もずっと厚い。 $\mathrm{S}$ 群もやや厚い橙 黄色の菌苔を作るが Pg4 では薄くて色も淡い。N群で は厌白色やや乾燥した菌苔を作り，Pg1, Pg5, Bg では 厚く $\mathrm{Bm} 1, \mathrm{Bt}$, 塩谷株では薄いことが多い。以上は鵎卵 培地上の一般所見で多くの菌株は10～18日後には発育の 盛期に達するが, Sf1, Pg2, Tp2 ではやや遅く, C106, Cc116 は最も遅く $3 \sim 4$ 週を要する。血清, 血液寒天,

Kirchner 寒天では発育が不良だがグリセリン牛心浸出 演寒天では極めて発育がよかった。ゲラチンでも發育は 引るく, 液化しない。種々の液体培地上での発青はP群 では極めてよく $3 \sim 4$ 週で厚い䲆のあ万菌膜を作るが， 墇， $\mathrm{N}$ 群では不良または生え難いものが多く， $\mathrm{P}$ 群も不 良 Sでともにかえって液底で少し発育方る。

b) 菌の染色性こ形態：菌株により培㖉の時期により 多少の差があり, P群は一般に大形で $7 \sim 8 \% \times 0.4-0.5 \mu$ 以上に達し屢々濃染部之淡染部が交互に $4 \sim 5$ コずつ並 んでおり，培地上では太い短桿菌となること多くやや多 形性を示す。 $\mathrm{N}$ 群は一般にやや繊細で， $\mathrm{P}^{\prime}$ 群は結核菌に 最あ近い形態上大きさを示す。定型的な分枝や分芽はな く菌糸を作らない。Sp, Sw 両株の超薄切片像では二重 構造の細胞膜, 細胞質膜, 核様構造など絬核菌に類似す るが、時に一端が明画な暗黒部になっている時もあった。 この他ミトコンドリア様棈造や種々の分裂像が見られる (Fig. 5)。抗酸性，抗酒精性は強い。10６。塩酸，硫 酸, 硝酸の脱色力見るに 1 時間では影嚮されない。し かし 3 时閒の作用では硫酸では影響されないが，塩酸で は60\%以上，硝酸ではそのほとんぞが脱色さ机た。抗煮 沸性：pH 7.0 蒸溜水を用い後染色なしに判定した。 $\mathrm{P}$ 群 $\mathrm{P}^{\prime}$ 群の 8 株は 7-10分, $\mathrm{S}$ 群も多く10分前後を示し たが $\mathrm{Gp}$ 株のみ 3 尔であった。 $\mathrm{N}$ 群も必音しも搦くなく 大抵 4-8 分にあったが，塩谷株だけが 1 分を示した。

c) 培養至適温度と温熱に対す万抵抗性：i）培盖至

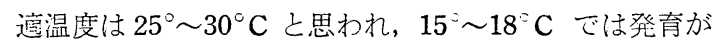

極めて不良, 3 週間後も陰性のものが少なくない。 $37^{\circ} \mathrm{C}$ での発育はさらに雭いが $\mathrm{P}^{\prime}$ 群で最も不良, $\mathrm{P}$ 群でも悪 いものが多かった。しかし, Pg3, Pg5 Bg, Gp 等では $25^{\circ} \mathrm{C}$ と大差がなかった。なお $\mathrm{C} 106, \mathrm{Cc} 116$ の両株は $25^{\circ} \mathrm{C}$ でも $37^{\circ} \mathrm{C}$ でもぼ同じでともに発育が最も遅か った。ii）温熱任対する抵抗：Sp, Sw, Pg2, Pg3 各株 は $40^{\circ} \mathrm{C}, 1$ 時間の作用で死滅に瀕し集落の解離が見ら れた。 $50^{\circ} \mathrm{C}, 1$ 時間ではほとんどの菌株に同様の現象が

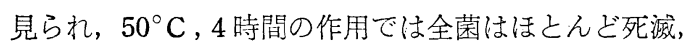
$55^{\circ} \mathrm{C}, 60^{\circ} \mathrm{C}$ 各 1 時間の作用で全菌株は全く死滅する。

d）食塩水中に保存した場合の菌の生存力約： $20 \mathrm{mg}$ の菌を 7〜 $8 \mathrm{ml}$ の生塩水中に投じ, 室温 $\left(10 \sim 30^{\circ} \mathrm{C}\right)$ に置 いて 1 月毎に小川培地に移植した。 9 力月後, $\mathrm{P}^{\prime}$ 群の Pg2, Sf1 株は死滅に瀕し, S 群中の Pg3, Pg4, Sf3 の 三株でも発育が不良であった。結核菌H37 R V, 青山B 両株は $37^{\circ} \mathrm{C}, 70$ 日の浸漬に耐え, 非定型菌 P1, P6, P7, P8 は90日以上屯生塩水室温の保存に耐えた。なお Thioglycolate 培地中でも発育は不良だが増殖可能のも のが多く, Pg1 Pg6 の 6 株之 P1 株でやや不良であっ た。

e）酸, 塩基に対する抵抗性：2 規定の塩酸, 硫酸, 硝酸之苛性ソーダ中に 4 時間菌草いた後, 中和して食 塩水を加え遠沈後, 小川培地に移植した結果によると, 硝 酸ではほとんぞの菌が死滅し, 塩酸でもLt株, Pg 2 株 は生存したが, Sp, Bg, C106, Cc116, Pg1 各株は死隇 した。硫酸，苛性ソーダに対しては抵抗が強く， Cc116 株が硫酸 4 時間の処理で死滅に瀕したのを見ただけであ る。

f) 二, 三抗結核剂に対方る抵抗性：10,6血清加 Kirchner 培地飞 INH, 1314Th, Chloromycetin(CM) Streptomycin (SM) を加えたものに $0.1 \mathrm{mg} / 0.1 \mathrm{ml} の$ 菌を加え $25^{\circ} \mathrm{C}$ においた。成績はTab. 2 亿示す通りでN 群中の Pg5 株が INH $1 \gamma$ で抑止されたほかは，P， S, $\mathrm{N}$ 各群の菌は INH に対し10 $\gamma$ 以上, 1314 Th に対し20 $\gamma$ 以上, $\mathrm{CM}$, SMに対しても20～ $50 \gamma$ 以上の抵抗性を 示すものが多かった。ただしP群の Pg2, Sf1 株が SM $1 \gamma$ で抑止さ机，ほかの薬剤にも5１0 でで発育を抑止さ れたのは注目される。PASに対しては束村2526)!従い 脱炭酸能（MA P テスト）它調べたところ， N 群の $\mathrm{Bg}$, $\mathrm{Pg} 5$ 両株は死黒〜茶褐となり, $\mathrm{P}$ 群でも $3 \sim 4$ 週より裩 色の色調を帯びた。 $\mathrm{S}$ 群と $\mathrm{P}^{\prime}$ 群ざはほとんど色調の変化 を見なかった。発育は路群ではかなり抑止さ机たが，ほ かは対照より少し不良の程度だった。しかるに鮭菌 S C O R両株は著明に抑止されて発育は極めて悪かった。

g）中性紅試験：Dubos-Middlebrook ${ }^{27)}$ によって行 
ったが，陽性を示すすのが多く， $\mathrm{P}^{\prime}$ 群では最強, $\mathrm{P}$ 群 では中等または弱陽性，S 群中の $\mathrm{C} 106, \mathrm{Cc} 116, \mathrm{Pg} 6$ は ほとんぞ陰性であった。既知の所謂魚結核菌 M. pis, M. mar, M. pl. は 3 株共陽性だったが， Ross の鮭株 4 株と M32 株は陰性であった。

h) Cord 形成能：定型的な Cord を形成するすのは少 なく，金魚に毒性の強いP群でさへその 5 株中 Lt 1 株 のみが Cord 形成を示した。 $\mathrm{S}$ 群では $\mathrm{Bm} 2$, 両株, $\mathrm{N}$ 群 では $\mathrm{Bg}$ と Bt 両株で Cord 形成を見た。 $\mathrm{P}^{\prime}$ 群 Sf1 で ははなはだ紛らわしかった。M. pis, M. mar., M. pl. はCord 形成を営なみ，䱦菌の 4 株でもこれが見られた。 (Fig. 6)

i) Peroxidase 反応 $\left(\right.$ Cathecol $-\mathrm{H}_{2} \mathrm{O}_{2}$ 法)：おおむね 陽性を示したが， S 群の C 106 株では陰性， Pg3, Sf3 株では弱陽性, N 群の Pg3 でも弱かった。鮭株でも弱 いむのが多い。

j) Catalase 試験: Schweizer et a1..28) によって行 い, Sf1, Sf3 が弱陽性だった以外，いずれむ強陽性を 示した。

k）メチレン青脱色能：ロッケマン培地に 2 万倍にな るよう色素を加え，菌を接種して $4 \sim 7$ 日後判定した。 ほとえごの菌で陰性だった。

1) Niacin 試験：今野によった。 $\mathrm{P}^{\prime}$ 群と $\mathrm{S}$ 群の計13 株では陰性だったが，P群 5 株中 Lt 株を除く 4 株では 明らかな陽性を示し，時には H37 R V 株のそれをしの ぐ強さであった。Benzidine-BrCN 法での着色が “Sp” 株で時に微紫色を帯びるてとから Niacin 以外の反応物 質の共存も考えられる。なお $\mathrm{N}$ 株中の P $1 ， \mathrm{Bg}$ 殊に Bg 株でも弱陽性を示したが，供試標本により陰陽が区 々であったが, 鮭菌 4 株でむ時により微弱陽性を呈し た。なお M. pis は陰性, M. mar は微弱陽性, M. pl. は明らかな陽性を示した（Tab. 3)

m) Amidase 試験：岡 ${ }^{29}$ らによった。Formamidase は B 1 株を除き拈おむ昖泩, Nicotinamidase は $\mathrm{P}$ 群の Lt, M. pis., S 群の大部分, N群中の Bg株之鰉菌 のSc 株が陰性だったてとが注目された。Urease はN群 を除けばおおむ称強陽性だったが， S 群の Cc116 株が弱 陽性，鰉菌注 4 株之も強陽性だったてとを注目したい。 (Table. 3)

\section{5）光発色性について}

既に述べたように魚より分離した抗酸菌24株中， 5 株 はRunyon のいう意味の光発色性をむち皆魚に対し一定 の病原性を示したが，そのうちの 1 株 Lt は定型的 cord 形成をなし，Niacin 試験は陰性，Nicotinamidase 陰性
という点がほかと相異した。前述結核菌㥞集落を作り, 徐々に橙黄色湾色するP'群をす Photo-chromogen に 入れてよいかどうかは一考を要する。既知魚結核菌中 M. pis. は酵素学的には Lt と一致し, M. mar. と M. $\mathrm{pl}$ は私の Pl, Sf $2, \mathrm{Sp}, \mathrm{Sw} の 4$ 株と一致する。乙の光 発色性は私の場合必ずしも不変な性質とばかりはいえな い上うに思われる。それは温血動物を通過せしめた後や 薬剂の影㗽により啔失したと思われる場合があったから で, 今後の研究課題で人の非定型抗酸菌の由来を考える 上にすこぶる重要な鍵となろう。

いずれにしてす光発色性は生菌にのみ見られる現象で 巷沸またはフオルマリン処理死菌には見られない。また 光量が少なすぎたが Beckmann 光電比色計で検したと ころでは波長 $370 \sim 420 \mathrm{~m} \mu$ と $550 \mathrm{~m} \mu$ 部に発色の peak があり, 赤外線では発色しない。発色した橙黄色の色素 （S P 株）をS 群であるPg 3 株の色素之比較するにと むに人参の色素とよく一致し (Fig. 6), $\mathrm{CH}_{3} \mathrm{OH}$ と $\mathrm{CH}$ $\mathrm{Cl}_{3}$ 等量液で抽出, $20 \%$ エーテル・石油エーテルでアル ミナ, カラムクロマトグラフィで分離した成績によると 本色素の主成分は束村や海老名 ${ }^{33}$ らのいうように $\beta$-carotine で $\alpha$-carotine む含まれ，このほか 3 種の色素 を混ずると思われる。Sp, Pg3 両菌株の色素の吸収曲線 を人参のそれと比較したのが Fig. 7である。

\section{6）魚から分離した抗酸菌の血清学的, 免疫学的検討の概略}

Tab. 4-a，4-b に示したようにP群の $\mathrm{Pl} ， \mathrm{Sp}$ 両株を 筋肉に接種した金魚の血清について凝集反応を検したと ころ，接種後 49〜225 日では160倍乃至 320 倍まで陽性 の成績を得た。また魚より分離した抗酸菌で免疫した家 鬼血清について相互の間に凝集反応および Ochterlony の寒天法で Hirano et $\mathrm{al}^{34)}$ に準じて抗原分析を試み興 味ある結果を得たが，詳細は別報するとして，てれらの 菌が結核菌のみならず非定型菌とむよく反応することを 知った (Fig. 8,9)。一方同種の魚からえたのに私の $\mathrm{Pl}$ 株之 M. PL (Baker 氏等の) 之は免疫学的には少し異 なる菌株であるととが明らかにさ机た。なお接種後 6 週 まで観察したところでは魚菌の多くは天答鼠にッ・アレ ルギィを起さなかった。

\section{7）魚より分離した抗酸菌の動物殊に金 魚への接種試験}

マウス: $0.1 \mathrm{mg}$ の静注では認むべき病変を起さず，時 に数カ月まで淋巴腺から菌を還元培養し得た。しかし 1 
〜2mgではしばしば急死する。天䇴鼠, 家鬼, 家鶏には 特に強い病原性があるとは思えなかった。蛙には毒性を むつ株が多い。金魚 (鯉, 鯂): 腹腔内接種では病原性の ない自然界抗酸菌でも器械的刺载の影響屯大きいし, 病 原性がなくても長期にわたって菌が滞溜しがちである。 筋肉内に $0.1 \mathrm{mg}(7 \sim 8 \mathrm{~g}$ 内外の魚) を接種する方法がよ いと思われる。なお検討中であるが $\mathrm{P}$ 群はほぼ一定した 病原性を持ち， $\mathrm{P}^{\prime}$ 群は案外弱いらしい。しかし $\mathrm{S}$ 群 (Bm2, C106, Cc116 等) 6強弱種々の毒性を示し, $\mathrm{N}$ 群 (Bt, Pg1, Pg5) 中にあ毒性を持つむのがある。同 時に金魚には病原性が少なくて熱帯魚には強いという場 合む考えられるから，その判定には慎重な今後の検討を 要する。病変は既述の熱帯魚の抗酸菌症のそれ之全く同 じで急激な場合または進行したものでは, 腎, 肝, 脾, 心などに鼠癩腫様の肉芽腫炎を, 慢性の埸合は結核結節 （栓塞血管の横断面を見るようである）を発生する。し かし急死を免れた魚は飼育管理さえよければ自然治㾮に 向い, 長く体内に少数の菌を蔵しつつ生存すると思われ る。また数種類の抗酸菌の協同作用屯考えられなくむな い。それは同一個体の熱帯魚から $2 \sim 4$ 株の菌株が分離 されたととが少くなかったてとから推想される。(Fig， 10,11 )。

\section{8）自然界抗酸菌殊に M. balnei や非 定型抗酸菌(狭義) との関係}

魚類抗酸菌症の原因菌が自然界抗酸菌殊に水系, 土系 のそれと深く関連するととは当然考えられることで, 従 来非病原性抗酸菌之いわれたすののなかにマウス，鮒な どに相当な毒性を示し, (Forbes et a1.35) 占部 ${ }^{36)}$, 中村 37)）中性紅反応, Cord 形成乞の他の生物学的性状む部 分的にせよ病原性抗酸菌のそれと通ずるあのがある（占 部 $\left.{ }^{38)}\right)$ などその関係は複雑である。近年 Schaffer et al. 39) は M. balnei と魚結核菌之の相似性を水中所在, 光 発色性などから強調した。私の研究でも人の非定型抗酸 菌 P6, P7, P8 などは魚にかなりの毒性をむち, 筋肉内 接種に続いて全身に拡がり,内臓殊に腎,脾に結核結節を 作り，しかも生物学的性状が相互に酷似するなど，魚類 抗酸菌症の原因菌之深い近縁関係を持つよう思われる。 これについての呤味殊に光発色性やナイアシン試験, 抗 原分析などの詳細については他の機会にゅずりたい。

\section{むすび}

私は熱帯魚から21株, 䫅菌を接種した金魚, 鮒から 3 株計 24 株の抗酸菌を分離し, その生物学的性状の概略を 述べ, あわせて魚類の抗酸菌症について略述, 既知の病
原, 非病原の諸種抗酸菌との比較にあ触れた。分離菌株 が多く, その詳細は今後の研究にまたねばならない。本 菌群の仔細な検討は人や動物の抗酸菌症, 殊に人の非定 型抗酸菌症之自然界抗酸菌との関連の解明に重要な示唆 を与えるむのと考える。なお Bergey の分類は魚結核菌 関する点についてはあらためらるべきである。

「本研究に多大の御援助之御示教を賜わった東北大 学農学部狩谷貞二助教授に深謝し, 材料採取に便宜を 与えられた松岛水族館の竹内健氏之東京上野動物園水 族館の久田迪夫氏に感謝する。」

$$
\text { 文献 }
$$

1) Bataillon, E., Duvard, et Terre, L.: Un nouveau type de tuberculose. Compt. rend. Soc. Biol. 49, 446 (1897)

2) Parisot, T.J.: Tuberculosis of fish. Bact. Rev., 22, 240 (1958)

3) Bertarelli, D. und Bocchia, J.: Neue Untersuchungen über die Tuberkulose der Kaltblüter. Zentralbl. Bakt., 54, 385 (1910)

4) Alexander, D.M. :文献 (2) Parisot, T.J.より引用

5) Sutherland, P.L.: A tuberculosis-like disease in a Salt-water fish (Halibut) associated with the presence of an acid-fast tubercle-like bacillus. J. Pathol. Bacteriol., 25, 31 (1922)

6) Aronson, J. D.: Spontaneous tuberculosis in salt water fish. J. Infect. Dis., 39, 315(1926)

7) Baker, J.A. and Hagan, W.A.: Tuberculosis of Mexican Platyfish (Platypoecillus maculatus). J. Infect. Dis., 70, 248 (1942)

8) Besse, P.: 文献(2)Parisot, T.J. より引用

9) Vogel, H.: Mycobacteria from cold-blooded animals. Amer. Rev. Tuberc., 77, 823 (1958)

10) Earp, B.J., Ellis, C.H., and Ordal, E.J.: Kidney disease in young salmon. 文献(2)Parisot, T.J. より引用

11) Wood, J., and Ordal, E.J.: 交献(2) Parisot, T. J. より引用

12) Ross, A.J.: Mycobacterium salmonifilum Sp, nov. from salmonoid fishes. Amer. Rev. Resp. Dis., 81, 241 (1960)

13) Aronson, J.D.: Tuberculosis of cold blooded animals. A review. Leprosy Briefs, 8, 21(1957)

14) Hutchinson, J.: 文献 (16) Bergel より引用

15) Creighton: 文献 (16) Bergel より引用 
16) Bergel, M. : Cuadros lepromatiformes en animals provocados por alimintation prooxidante. Leprologia, 1, 46 (1956)

17) Sato, S., Mayama, A.: Inoculation experiment of leprosy in goldfish and crucian. I. Brief comparison of the results obtained by inoculation with lepra bacilli and those obtained with tubercle or saprophytic acid-fast bacilli Sci. Rep. Tohoku Univ., -c. 10, 185 (1961)

18) Sato, S., Mayama, A. and Fukuda, M.: Inoculation experiment of leprosy in goldfish and crucian. II. Results with murine leprosy bacilli. Sci. Rep. Tohoku Univ., -c. 10, 234 (1961)

19) Chaussinand, R. et Besse, P.: Inoculation du bacille de Hansen et du bacille de Stetansky à la perche arc-en- ciel (Eupomotis gibbosus). Note peéliminaire. Rev. Brasil. Leprol., 19, 4 (1951)

20）高山保郎：癩菌の異種動物接種に関する研究 第 4 報, 鮒に対する鼠癩菌接種実験, 広帠医学 (原著) 4 巻1328頁 (1956)

21）中村加代子:雑菌性ミコバクテリウムの研究一いわ ゆる Atypical acid-fast bacteria との異同它雇 慮して, 第 3 編, マウス以外の実験動物に対与る病 原性の検討，結核，36，263 (1961)

22) Ross, A.J. Personal Communication

23) Runyon, E.H.: Mycobacteria encountered in clinical laboratories. Leprosy Briefs, 9, 21 (1958) (abst.)

24）越智勇一, 佐藤軍二, 非病原抗酸菌の研究 I 牛 からの分離および形態学について, 細菌誌, 16 , 1068 (1961)

25）束村道雄：PAS から赤褐色物質を産生する抗酸菌 の1群，医学々生物学，60，5 (1961)

26）束村道雄：PAS 加赤褐色物質を産生する抗酸菌 の 1 群, 続報, 赤褐色物質の生化学的性状ならで にPAS $2 \mathrm{mg} / \mathrm{ml} 1$ \% 小川培地による M. tuberculosis と nonphotochromogen の区別，医学々生 物学, 60, 92 (1961)

27) Dubos, R.J. and Middlebrook, R. : Cytochemical reaction of virulent tubercle bacilli. Amer. Rev. Tuberc., 58, 698 (1948) (Letters)

28) Schweizer, O. and Romàn, E., and Soós, I.: Studies on the catalase enzyme of mycobacteria under certain experimental conditions. Amer. Rev. Tuberc., 77, 146 (1958)

29）今野淳, 長山英男, 岡捨已：ナイアシンテストの検 討, 日胸, 20,897, 1961

30）岡捨己, 今野淳, 長山英男, 工藤穠：抗酸菌の生化 学的分類, 日本胸部臨床，20，797 (1961)

31) 束村道雄: 非定型抗酸菌 (Photochromogenおよび Scotochromogen) の Carotenoid 色素, 医学と生 物学, 61巻, 5頁 (1961)

32) 束村道雄: 非定型抗酸菌 (Photochromogen) の Carotenoid 色素 (第 2 報) 医学上生物学, 61, 63 (1961)

33）海老名敏明, 本宮雅吉, 宗形喜久男, 份竹央行:棐 定型抗酸菌 Photochromogen No. 8 及び Scotochromogen No. 6 の色素について, 結核, 37(特) 49 (1962) (学会)

34) Hirano, N., and Sushida, K.: Serological relationship between mycobacteria as determined by agar diffusion precipitation test. Japanese J. Microbiol., 4, 303 (1960)

35) Fores, W.D., Cuttino. J.T., Smith, A.C., Margolis, A.M. C., and Reid, D.W.: A Comparative study of for groups of acid-fast organisms, with special reference to pathogenicity. A.M. A. Arch. Path., 66, 1 (1958)

36）占部薫：非定型抗酸菌の病原性，医学のあゆみ, 34, 413 (1960)

37）中村加代子：雑菌性ミコバクテリゥムの研究一い わ泫る Atypical acid-fast bacteria との異同を 顧慮して, 第 2 編, マウス病原性の詳細, 結核, 36 201 (1961)

36）占部薫：いわゆる非定型抗酸菌をめぐって,胸部疾 患, 3, 305 (1959)

39) Schaffer. W.B. and Davis. C.L.: A bacteriologic and histopathologic study of skin granuloma due to mycobacterium balnei. Amer. Rev. Resp. Dis., 84, 837 (1961) 